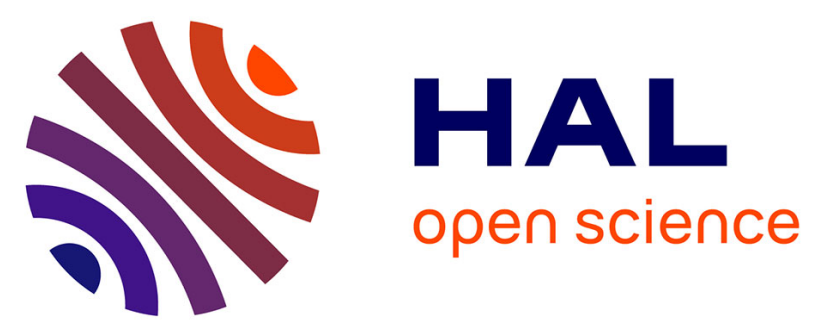

\title{
Effects on renal function of obstructive and nonobstructive dilatation of the upper urinary tract in ileal neobladders with refluxing ureteroenteric anastomoses
}

R. Minervini, R. Pagni, C. Mariani, A. Morelli, G. Morelli, A. Minervini

\section{To cite this version:}

R. Minervini, R. Pagni, C. Mariani, A. Morelli, G. Morelli, et al.. Effects on renal function of obstructive and nonobstructive dilatation of the upper urinary tract in ileal neobladders with refluxing ureteroenteric anastomoses. EJSO - European Journal of Surgical Oncology, 2010, 36 (3), pp.287. 10.1016/j.ejso.2009.09.003 . hal-00566744

\author{
HAL Id: hal-00566744 \\ https://hal.science/hal-00566744
}

Submitted on 17 Feb 2011

HAL is a multi-disciplinary open access archive for the deposit and dissemination of scientific research documents, whether they are published or not. The documents may come from teaching and research institutions in France or abroad, or from public or private research centers.
L'archive ouverte pluridisciplinaire HAL, est destinée au dépôt et à la diffusion de documents scientifiques de niveau recherche, publiés ou non, émanant des établissements d'enseignement et de recherche français ou étrangers, des laboratoires publics ou privés. 


\section{Accepted Manuscript}

Title: Effects on renal function of obstructive and nonobstructive dilatation of the upper urinary tract in ileal neobladders with refluxing ureteroenteric anastomoses

Authors: R. Minervini, R. Pagni, C. Mariani, A. Morelli, G. Morelli, A. Minervini

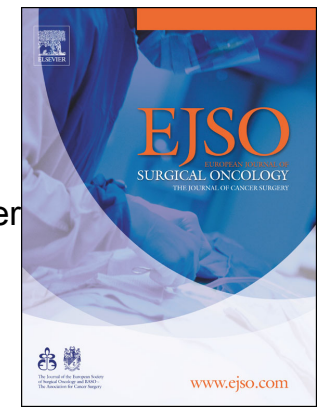

PII:

S0748-7983(09)00464-8

DOI:

10.1016/j.ejso.2009.09.003

Reference: $\quad$ YEJSO 2889

To appear in: European Journal of Surgical Oncology

Received Date: 29 March 2009

Revised Date: 1 September 2009

Accepted Date: 10 September 2009

Please cite this article as: Minervini R., Pagni R., Mariani C., Morelli A., Morelli G., Minervini A. Effects on renal function of obstructive and nonobstructive dilatation of the upper urinary tract in ileal neobladders with refluxing ureteroenteric anastomoses, European Journal of Surgical Oncology (2009), doi: 10.1016/j.ejso.2009.09.003

This is a PDF file of an unedited manuscript that has been accepted for publication. As a service to our customers we are providing this early version of the manuscript. The manuscript will undergo copyediting, typesetting, and review of the resulting proof before it is published in its final form. Please note that during the production process errors may be discovered which could affect the content, and all legal disclaimers that apply to the journal pertain. 


\section{EFFECTS ON RENAL FUNCTION OF OBSTRUCTIVE AND NONOBSTRUCTIVE DILATATION OF THE UPPER URINARY TRACT IN ILEAL NEOBLADDERS WITH REFLUXING URETEROENTERIC ANASTOMOSES}

R Minervini, R Pagni, C Mariani, A Morelli, G Morelli, *A Minervini .

Department of Surgery, Urology Unit, University of Pisa, Pisa, Italy

* Department of Urology, University of Florence, Careggi Hospital, Florence, Italy.

KEYWORDS: orthotopic ileal neobbladder, urinary diversion, direct anastomosis, reflux, anastomotic stricture, renal function.

CORRESPONDENCE:

Andrea Minervini, MD, PhD

Clinica Urologica I, Azienda Ospedaliera Careggi, Università di Firenze,

Villa Monna Tessa, Viale Pieraccini 18, 50139, Firenze, Italia.

Tel. ++39 055 417645; Facsimile. ++39 0554377755

Email. andreamine@libero.it 
Aims. To investigate the incidence and long term effects on kidney function of obstructive and nonobstructive dilatation of the upper urinary tract in patients with ileal neobladder with refluxing ureterointestinal anastomoses.

Methods We retrospectively analyzed a prospectively derived database of 110 patients with bladder cancer and who were treated with an ileal neobladder between 1996 and 2007 using refluxing endto-side ureterointestinal anastomoses on a short afferent limb. The mean follow up was 65 months. At every follow up visit the patients had an analysis of serum creatinine, urine culture, abdominal CT or ultrasonography, and, if there was dilatation of the upper urinary tract, 99mTc- DTPA renal scintigraphy was requested.

Results. In all, 206 renoureteral units were included in the study. Overall, seven had anastomotic stricture and of those, three were symptomatic and were corrected; while four were asymptomatic and of those, only two, with preserved split GFR, were surgically treated, while the remaining two, with a poor split GFR, were followed up. The last 99mTc-DTPA showed a preserved split GFR in the reimplanted units and further split renal function decrease in untreated units. Nonobstructive dilatation of the upper urinary tract, caused by reflux, was diagnosed in 13 units. The dilatation was bilateral in three patients with recurrent UTIs and urosepsis, and the split GFR was bilaterally reduced at diagnosis with a further reduction at the last 99mTc-DTPA. The remaining seven units with sterile urine, showed a preserved split GFR during follow up.

Conclusions. All strictures, regardless of their severity, should be immediately corrected. Reflux per se does not provoke renal impairment unless recurrent UTIs and urosepsis are present. 


\section{EFFECTS ON RENAL FUNCTION OF OBSTRUCTIVE AND NONOBSTRUCTIVE DILATATION OF THE UPPER URINARY TRACT IN ILEAL NEOBLADDERS WITH REFLUXING URETEROENTERIC ANASTOMOSES}

\section{INTRODUCTION}

Radical cystectomy is the treatment of choice for muscle-invasive bladder cancer ${ }^{1}$ and even if recent reports have shown that patients with a neobladder enjoy marginal quality of life advantages over those with an ileal conduit ${ }^{2-4}$, orthotopic bladder reconstruction remains the best option for patients undergoing cystectomy ${ }^{5,6}$.

In patients with a neobladder, the preservation of renal function is the ultimate goal of successful treatment ${ }^{7}$ and can be influenced by several factors including ureteral obstruction, urinary tract infection (UTI) and reflux ${ }^{8-10}$.

Dilatation of the upper urinary tract is the major concern in ureteroileal anastomosis ${ }^{11}$ and can be caused by strictures of the ureter and reflux ${ }^{7}$.

The general question is whether a refluxing or nonrefluxing technique should be chosen. Proponents of nonrefluxing techniques cite the harmful effects on renal function of recurrent pyelonephritis caused by reflux ${ }^{9,10}$ and bacteriuria ${ }^{8}$ and the potential benefit in patients undergoing intermittent catheterization. Nevertheless, the danger to renal function caused by anastomotic stricture that occurs at a higher rate after an antirefluxing technique than after direct anastomosis is well documented ${ }^{5,12,13}$ and it is reflected by the number of different antireflux mechanisms developed during the years, such as afferent nipple valves ${ }^{14}$, the Le Duc technique ${ }^{15}$, split-cuff ureteral nipples ${ }^{16}$, the Abol-Enein and Ghoneim technique ${ }^{17}$, the T pouch tecnique ${ }^{18}$ and an afferent ileal tubular segment ${ }^{19}$; however, the multiplicity of these techniques suggests that an ideal solution has not yet been found. 
On the contrary, using a direct anastomosis, anastomotic strictures occur at a significantly lower rate than after an antireflux technique ${ }^{5}$, but ureteral reflux might potentially endanger kidney function on the long term follow up ${ }^{10}$.

In this study we investigated the incidence of obstructive and nonobstructive dilatation of the upper urinary tract, caused by ureterointestinal stricture and reflux, respectively, and their impact on split renal function in the long term in patients who had a low pressure ileal neobladder constructed using refluxing ureterointestinal anastomoses.

\section{MATERIALS AND METHODS}

\section{$\underline{\text { Patients Population }}$}

A prospective derived database of patients undergoing ileal neobladder for bladder cancer was retrospectively analyzed. Between May 1996 and March 2007, 110 consecutive men (mean age 63.8 years, range 45-79) underwent radical cystectomy and orthotopic neobladder formation. Inclusion criteria for continent urinary diversion were normal renal function, absence of gastrointestinal disease and absence of tumor at the prostatic urethra. Preoperative evaluation included serum creatinine, ultrasonography and computerized tomography of the abdomen and pelvis. Mean (range) preoperative serum creatinine was $0.99 \mathrm{mg} / \mathrm{dl}$ (0.7-1.5, normal 0.7-1.4) (87.5 $\mu \mathrm{mol} / \mathrm{L}$, range 62-133, normal 62-124).

\section{Surgical Technique}

In all cases, the W-shaped ileal neobladder and ureteral anastomoses on a short afferent limb were done according to our previously described standard technique using 45 to $47 \mathrm{~cm}$ of ileum ${ }^{7,20}$. The distal $40 \mathrm{~cm}$ were detubularized on a silicone tube and oriented into a "W" shape, the proximal 5 to $7 \mathrm{~cm}$ left intact for anastomosis with the ureters. The ureters were spatulated and implanted to the ileal chimney using the Nesbit nontunneled end- to- side ureteroileal anastomosis with 2 running 50 absorbable sutures. 


\section{Evaluation of renal function during follow up}

The patients were routinely examined every 6 months for the first 3 years and yearly thereafter. At every follow up visit the patients underwent serum creatinine, urine culture, abdominal CT scan or ultrasonography, and, in case of dilatation of the upper urinary tract at the imaging study, 99mTcDTPA renal scintigraphy with a Foley catheter in the neobladder was requested to evaluate total and split GFR and to define the cause of the dilatation: obstructive, caused by anastomotic stricture or nonobstructive, caused by reflux.

The dilatation was considered obstructive if appearance of the radioisotope in the pelvicaliceal system was delayed, if there was retention of activity in the dilated collecting system over time and if $T^{1} \frac{1}{2}$ of the time-activity curve was greater than 20 minutes after intravenous administration of furosemide. Nonobstructive dilatation was assumed if the collecting system was dilated and the T1/2 of the time-activity curve was less than 10 minutes after furosemide injection.

Total and split renal function of patients with obstructive and nonobstructive dilatation was evaluated by measurements of plasma creatinine and GFR. Plasma creatinine was measured with the standard autoanalyzer technique. Standard 99mTc-DTPA renal scintigraphy and Gates' method were used to calculate GFR. GFR values measured as the renal clearance of 99mTc-DTPA are reported with reference to the standard body surface area of $1.73 \mathrm{~m}^{221,22}$.

Clean catch urinalysis and urine cultures were done according to standard sterile procedures. UTI was defined as a urine culture showing greater than 10,000 cfu bacteria plus suprapubic pain or greater than 100,000 cfu bacteria with or without symptoms. Urosepsis was defined as greater than 100,000 cfu bacteria in the urine plus evidence of a positive blood culture ${ }^{8}$.

The final evaluation of patients status was in March 2008. The mean follow up was 65 months (range 12 to 141 ). A total of 40 patients died during follow up, 32 of bladder carcinoma and eight of causes independent from bladder tumor. 


\section{RESULTS}

Of the 110 patients, two died in the perioperative period and three were lost to follow-up. Of the 105 patients (210 renoureteral units), two had resection of the distal ureter and reimplantation for recurrent disease at 50 and 62 months after surgery and two had nephroureterectomy for upper urinary tract transitional cell carcinoma at 45 and 58 months after surgery. Therefore this study is based on a series of 206 renoureteral units (105 patients) and of those 20 units (17 patients) showed a dilatation detected during follow up and were further investigated.

\section{Obstructive dilatation}

Overall, in our series, seven renoureteral units had anastomotic stricture (Table 1) and of those, three had symptomatic anastomotic stricture detected at 2, 4 and 8 months after surgery (three renal units). These patients were treated with surgical reimplantation. Four patients had anastomotic stricture detected as asymptomatic dilatation of the upper urinary tract at 6, 12, 24 and 24 months after surgery (four renal units). The split GFR in these four patients was 45, 40, 21 and 26.3 $\mathrm{ml} /$ minute respectively and only patients with split GFR of 45 and $40 \mathrm{ml} /$ minute were treated with surgical reimplantation. The nuclear renography at 6 months after diagnosis showed a GFR of 43.2 and $38.2 \mathrm{ml} /$ minute, respectively, in patients treated with surgical reimplantation. The resolution of the anastomotic stricture was confirmed at the last follow up visit at 56 and 74 months after surgery with a split GFR of 39.2 and $34.8 \mathrm{ml} /$ minute, respectively. There was a decrease to 14.2 and 16.3 $\mathrm{ml} /$ minute at the last nuclear renography performed 36 and 48 months after diagnosis in patients that were not treated.

\section{Nonobstructive dilatation}

The renal scan revealed nonobstructive dilatation of the upper urinary tract in ten patients (Table 2). The dilatation was bilateral in three patients with recurrent UTIs and urosepsis. The split GFR in these patients at diagnosis was 22/25, 31.2/33.2 and 27.6/28.3 ml/minute, and showed a further 
reduction to $15 / 17,19 / 25.2$ and $21.1 / 25.3 \mathrm{ml} /$ minute at the last nuclear renography performed at 17, 47 and 51 months after surgery.

The dilatation was unilateral and moderate in the remaining seven patients, with sterile urine or one positive urinalysis during follow up. These patients showed a preserved split GFR symmetrical with the nondilated renal unit, with a mean of $47.3 \mathrm{ml} /$ minute at diagnosis that did not showed a significant reduction during follow up after a further mean (range) follow up of 44 (36-51) months (Table 2).

\section{DISCUSSION}

Reflux prevention in orthotopic bladder substitutes remains a controversial issue and although excellent long term results have been described using refluxing anastomoses, many surgeons continue to perform antireflux procedures ${ }^{23}$.

The aim of the present study was to investigate the incidence of obstructive and nonobstructive dilatation of the upper urinary tract and their impact on split renal function on the long term in patients who had a low pressure ileal neobladder constructed using refluxing ureterointestinal anastomoses. Unfortunately our patients did not have a preoperative renal scan and this can be considered the main bias of this study but all patients had a thorough preoperative evaluation that included serum creatinine, ultrasonography and computerized tomography and all the 17 patient showing postoperative upper tract dilatation either due to stricture or reflux presented a normal morphology of the upper urinary tract before surgery associated with normal serum creatinine. Anastomotic stricture: refluxing vs nonrefluxing techniques

All ureterointestinal anastomoses, whether antireflux or not, have an inherent risk of stricture with consequent ureteral obstruction and, thus, potential renal impairment. However, this risk appears, to be appreciatively higher after an antireflux technique than after direct anastomosis, irrespective of the anastomosis technique and the segment of bowel used ${ }^{11,24,25}$ with a reported stricture rate of 1$4 \%$ for the direct anastomosis and of $9.5-20 \%$ for the different antireflux techniques described in 
the literature ${ }^{5,7,12,26,27}$. Better results were reported by Osman et al. with a 5.1\% obstruction rate using the serous lined extramural tunnel technique ${ }^{28}$, and by Skinner with the ileal T pouch neobladder ${ }^{18}$. However, the T mechanism is not easy to construct, time-consuming and yet to be widely adopted.

\section{Anastomotic stricture: long- term effects on renal function and treatment options}

In our series, using a Nesbit nontunneled end- to- side ureteroileal anastomosis the stricture rate was $3.4 \%$ and in three over seven cases the strictures caused acute symptoms such as flank pain and fever. All symptomatic strictures occurred within the first 8 months after surgery and all were treated with open reimplantation. Others proposed the endourological treatment that consists in balloon dilatation or incision of the stricture due to its lower morbidity in comparison to the open surgical treatment ${ }^{29}$, but we, and others consider the open surgical revision as the preferred method for its significantly higher success rate ${ }^{12}$.

Another possible presentation of anastomotic strictures is in asymptomatic patients during follow up imaging showing unilateral hydronephrosis possibly associated with signs and symptoms of UTIs, pyelonephritis and increased serum creatinine. In our series, four anastomotic strictures were diagnosed during follow up in asymptomatic patients. We opted for open surgical treatment in two cases with a preserved split GFR at renal scintigraphy while decided for a close follow up in the other two patients due to the very poor split renal function of the obstructed unit with a preserved contralateral kidney function that in our view lowered the advantages of the surgical correction associated with all the possible complications of this type of surgery. Nevertheless, in these two patients, the last nuclear renography performed 3 and 4 years after diagnosis showed a further significant decrease of the split GFR. Therefore, we believe that all strictures, once detected, should be treated surgically with reimplantation because also asymptomatic strictures invariably lead to deterioration of kidney function during follow up.

\section{Long-term effects of reflux on renal function}

While the danger to renal function caused by anastomotic stricture is well documented in orthotopic 
neobladders, the benefits of reflux prevention are only clear for the continent cutaneous pouch requiring intermittent catheterization and for ureterosigmoidostomy, both usually showing high reservoir pressures and bacteriuria ${ }^{30}$. However, in the orthotopic neobladder, which is a low pressure reservoir with no major coordinated contractions and either with sterile urine or with asymptomatic bacterial colonization, the benefits related to reflux prevention are not well documented $^{25}$.

All literature data suggest that even if present, reflux per se, does not provoke renal impairment unless infected urine is present. Indeed, most clinical and experimental studies show the important role of UTI together with reflux in the development of reflux nephropathy scars $9,10,25$. Moreover, asymptomatic bacterial colonization is not sufficient to cause renal damage but recurrent UTIs are; the latter occurring especially in women with hypercontinence and in men with severe voiding dysfunction ${ }^{8}$. In our series we confirm this assumption. Indeed, of the ten patients with nonobstructive dilatation caused by reflux, only three who had recurrent UTI and urosepsis had a severe reduction of parenchymal uptake during follow up, while the remaining seven patients, with sterile urine or one positive urinalysis during follow up, showed a preserved split GFR symmetrical with the not dilated renal units, that did not showed a significant reduction during follow up.

\section{CONCLUSIONS}

The direct, end-to-side Nesbit ureteroenteric anastomosis is a safe and acceptable technique for ureteral reimplatation in low pressure ileal neobladder, it provides excellent long-term results with a low stricture rate. All strictures, once detected, should be treated surgically with reimplatation because even asymptomatic strictures can lead to deterioration of kidney function during follow up. Reflux per se does not provoke renal impairment unless recurrent UTIs and urosepsis are present. In the latter, a progressive decrease in kidney function is awaited.

\section{REFERENCES}

1. Oosterlinck W, Lobel B, Jakse G. Guidelines on bladder cancer. Eur Urol 2002; 41(2):105-12. 
2. Porter MP, Penson DF. Health related quality of life after radical cistectomy and urinary diversion for bladder cancer: a systematic review and critical analysis of literature. J Urol 2005; 173:1318-1322.

3. Porter MP, Wei JT, Penson DF. Quality of life issues in bladder cancer patients following cystectomy and urinary diversion. Urol Clin North Am .2005; 32:207-216.

4. Elmar W Gerharz .Is there any evidence that one continent diversion is any better than any other or than ileal conduit? Curr Opin Urol .2007; 17:402-407.

5. Hautmann RE. Urinary diversion: ileal conduit to neobladder. J Urol. 2003; 169:834-842.

6. Studer UE, Burkhard FC, Schumacher M et al. Twenty years experience with an ileal orthotopic low pressure bladder substitute-lesson to be learned. J Urol 2006; 176:161-166.

7. Minervini A, Boni G, Salinitri G, et al. Evaluation of renal function and upper urinary tract morphology in the ileal orthotopic neobladder with no antireflux mechanism. J Urol 2005; 173: 144-147.

8. Wood Jr DP, Bianco Jr FJ, Pontes JE et al. Incidence and significance of positive urine cultures in patients with an orthotopic neobladder, J Urol 2003; 169: 2196-2199.

9. Okur H, Köse O, Kula M, et al. The role of infection and free oxygen radical damage in reflux nephropathy: an experimental study, J Urol 2003; 169: 1874-1877

10. Ransley PG and Risdon RA. Reflux and renal scarring, Br J Radiol 1978; 14 (1):45-54.

11. Stein JP, Freeman JA, Esrig D, et al. Complications of the afferent antireflux valve mechanism in the Koch ileal reservoir. J Urol 1996; 155:1579-1584

12. Pantuck AJ, Han K-R, Perrotti M, Weiss RE et al. Ureteroenteric anastomosis in continent urinary diversion: long-term results and complications of direct versus nonrefluxing techniques. J Urol 2000; 163: 450-455

13. Ayman AH, Samir AE, Magdy AS, et al. Evaluation of direct versus non refluxing technique and functional results in orthotopic Y ileal neobladder after 12 years after follow up. Int J Urol 2007;14: 300-304. 
14. Kock NG, Nilson AE, Nilsson LO, et al. Urinary diversion via a continent ileal reservoir: clinical results in 12 patient. J Urol 1982; 128: 469-475

15. Le Duc A, Camay M and Teillac P. An original antireflux ureteroileal implantation technique. Long term follow up. J Urol 1987; 137: 1156-1158

16.Sagalowsky AI., Early results with split-cuff nipple ureteral reimplants in urinary diversion. J Urol 1995; 154: 2028-2031.

17. Abol-Enein H and Ghoneim MA. A novel uretero-ileal reimplantation technique: the serous lined extramural tunnel. A preliminary report. J Urol 1994; 151:1193-1194.

18. Stein JP, Lieskovsky G., Ginsberg DA et al. The T-pouch: an orthotopic ileal neobladder incorporating a serosal lined ileal antireflux technique. J Urol 1998; 159: 1836-1842

19. Studer UE, Danuser M, Springer JP et al. Experience in 100 patients an ileal low pressure bladder substitute combined with an afferent tubular isoperistaltic segment. J Urol 1995; 154: 49-56 20. Minervini R, Morelli G, Fontana N, et al. Functional evaluation of different ileal neobladders and ureteral reimplantation techniques. Eur Urol 1998; 34: 198-202

21. Mulligan JS, Blue PW, Hasbargen JA. Methods for measuring GFR with technetium-99mDTPA: an analysis of several common methods. J Nucl Med 1990; 31: 1211-1219

22. Inoue Y, Ohtake T, Homma Y, et al. Evaluation of glomerular filtration rate by camera-based method in both children and adults. J Nucl Med 1998; 39: 1784-1788

23. Skinner E.C. and Skinner D.G. Does reflux in orthotopic diversion Matter? A randomized prospective comparison of the Studer and T-pouch ileal neobladders. World J Urol 2009; 27: 51-55 24.Yang WJ, Cho KS, Rha KH, et al. Long term effects of ileal conduit urinary diversion on upper urinary tract in bladder cancer, Urology 2006; 68(2): 324-327.

25. Burkhard FC, Kessler TM, Mills R, et al. Continent urinary diversion. Critical Reviews in Oncology/Hematology 2006; 57: 255-264.

26. Roth S, Van Ahlen H, Semjonow A, et al. Does the success of ureterointestinal implantation in orthotopic bladder substitution depend more on surgeon level of experience or choice of technique? 
J Urol 1997; 157: 56-

27. Studer UE and Zingg EJ. Ileal orthotopic bladder substitutes. What we have learned from 12 years' experience with 200 patients. Urol Clin North Am 1997; 24: 781-793

28. Osman Y, Abol-Enein H, Nabeeh A, et al. Long-term results of a prospective randomized study comparing two different antireflux techniques in orthotopic bladder substitution. Eur Urol 2004; 45: 82-86

29. Kramolowsky EV, Clayman RV, Weyman PJ. Management of ureterointestinal anastomotic strictures: comparison of open surgical and endourological repair.J Urol1988;139(6):1195-8. 30. Hautmann R.E., Abol-enein H., Afez K., et al. Urinary diversion. Urology 2007 ; 69 (1A):17-49 


\section{CONFLICT OF INTEREST}

We confirm that:

1. All authors have made a substantial contribution to the manuscript: "EFFECTS ON RENAL FUNCTION OF OBSTRUCTIVE AND NONOBSTRUCTIVE DILATATION OF THE UPPER URINARY TRACT IN ILEAL NEOBLADDERS WITH REFLUXING URETEROENTERIC ANASTOMOSES” submitted for publication.

2. All have read and approved the final manuscript.

3. All have no commercial relationship such as consultancies, stock ownership or other equity interests, patents received and/or pending, or any commercial relationship which might be in any way considered related to the abovementioned submitted article.

4. The manuscript or portions of it are not under consideration by another journal or electronic publication and have not been previously published elsewhere.

5. No financial support has been received for this research/study.

The Authors:

Prof. R. Minervini, MD

Dr. R. Pagni, MD

Dr. C. Mariani, MD

Dr. A. Morelli, MD

Dr. G. Morelli, MD

Dr. A. Minervini, MD, PhD 
Tab.1: GFR and characteristics of the 7 patients with obstructive dilatation of the upper urinary tract.

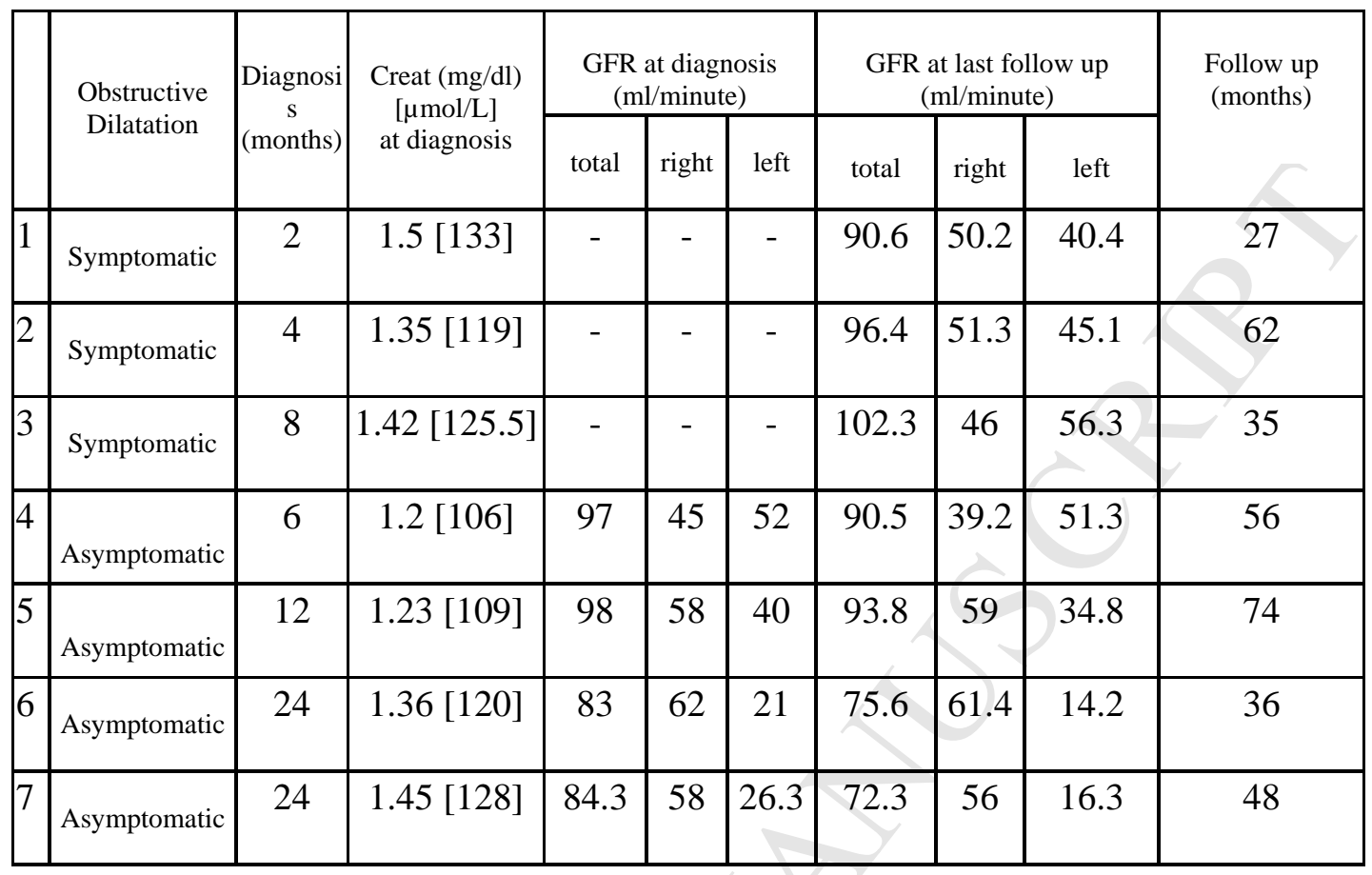


Tab. 2: GFR and characteristics of the 10 patients with non-obstructive dilatation of the upper urinary tract.

\begin{tabular}{|c|c|c|c|c|c|c|c|c|c|c|}
\hline & \multirow{2}{*}{$\begin{array}{l}\text { Unobstructive } \\
\text { Dilatation }\end{array}$} & \multirow{2}{*}{$\begin{array}{l}\text { Diagnosis } \\
\text { (months) }\end{array}$} & \multirow{2}{*}{$\begin{array}{c}\text { Creat }(\mathrm{mg} / \mathrm{dl}) \\
{[\mu \mathrm{mol} / \mathrm{L}]} \\
\text { at diagnosis }\end{array}$} & \multicolumn{3}{|c|}{$\begin{array}{l}\text { GFR at diagnosis } \\
\text { (ml/minute) }\end{array}$} & \multicolumn{3}{|c|}{$\begin{array}{l}\text { GFR at last follow up } \\
\text { (ml/minute) }\end{array}$} & \multirow[t]{2}{*}{$\begin{array}{l}\text { Follow up } \\
\text { (months) }\end{array}$} \\
\hline & & & & total & right & left & total & right & left & \\
\hline 1 & $\begin{array}{c}\text { bilateral } \\
\text { Recurrent UTI }\end{array}$ & 21 & 1.28 [113.5] & 47 & 22 & 25 & 32 & 15 & 17 & 17 \\
\hline 2 & $\begin{array}{c}\text { bilateral } \\
\text { Recurrent UTI }\end{array}$ & 22 & $0.8[71]$ & 64.4 & 31.2 & 33.2 & 44.2 & 19 & 25.2 & 47 \\
\hline 3 & $\begin{array}{c}\text { bilateral } \\
\text { Recurrent UTI }\end{array}$ & 25 & 1.25 [110.5] & 55.9 & 27.6 & 28.3 & 46.4 & 21.1 & 25.3 & 51 \\
\hline 4 & $\begin{array}{l}\text { Monolateral } \\
\text { No UTI }\end{array}$ & 42 & 1.07 [95] & 106.5 & 53.7 & 52.8 & 102.6 & 52 & 50.6 & 36 \\
\hline 5 & $\begin{array}{l}\text { Monolateral } \\
\text { No UTI }\end{array}$ & 90 & $1.31[116]$ & 84.6 & 45 & 39.6 & 82.4 & 46 & 36.4 & 39 \\
\hline 6 & $\begin{array}{l}\text { Monolateral } \\
\text { No UTI }\end{array}$ & 83 & 1.12 [99] & 106.5 & 53.5 & 53 & 103.1 & 53 & 50.1 & 46 \\
\hline 7 & $\begin{array}{l}\text { Monolateral } \\
\text { No UTI }\end{array}$ & 27 & $1.14[101]$ & 106.8 & 53 & 53.8 & 103.8 & 53 & 50.8 & 48 \\
\hline 8 & $\begin{array}{l}\text { Monolateral } \\
\text { No UTI }\end{array}$ & 52 & $1.27[112]$ & 106.2 & 52.9 & 53.3 & 102.8 & 50.1 & 52.7 & 44 \\
\hline 9 & $\begin{array}{l}\text { Monolateral } \\
\text { No UTI }\end{array}$ & 48 & 1.35 [119] & 85.1 & 43.8 & 41.3 & 81.9 & 43.2 & 38.7 & 42 \\
\hline 10 & $\begin{array}{l}\text { Monolateral } \\
\text { No UTI }\end{array}$ & 31 & 1.4 [124] & 80.7 & 38.2 & 42.5 & 76.9 & 35.4 & 41.5 & 51 \\
\hline
\end{tabular}

